\title{
Peat ash and basic slag as substitutes for lime with reference to phosphorus uptake by turnip rape
}

\author{
HELINÄ HARTIKAINEN \\ University of Helsinki, Department of Agricultural Chemistry, \\ 00710 HELSINKI, Finland
}

\begin{abstract}
The effect of peat ash and basic slag on the P supply to turnip rape was compared with that of calcitic and dolomitic limestone in a pot experiment performed with two acid mineral soils of $\mathrm{pH} 4.8\left(\mathrm{CaCl}_{2}\right)$. Changes in soil properties induced by various liming agents were investigated in an analogous incubation test, and the results served to interpret the observations made in the pot experiment.

When the liming materials were added in equal quantities, their ability to reduce soil acidity decreased in the sequence: calcite $>$ dolomite $>$ basic slag $>$ peat ash. However, their growth-promoting effect appeared only in the second year and was not related to the neutralizing ability. In the muddy fine sand soil (3.0 \% of org. C) poor in water-soluble P, the peat ash and basic slag were equally effective as calcite in increasing the dry matter yields. In the fine sand soil ( $6.4 \%$ of org. $\mathrm{C})$, the basic slag and dolomite significantly increased the second yield.

The efficiency of peat ash and basic slag seemed to be attributable to their positive impact on $\mathrm{P}$ resources. In fact, peat ash served as a slowly acting P-fertilizer rather than as a liming agent. In the basic slag treatment, an increased silicate concentration obviously resulted in desorption of P. In the P-deficient muddy fine sand, the peat ash was equivalent to calcite in intensifying the $\mathrm{P}$ uptake. On the other hand, in the fine sand soil where the polymerization of $\mathrm{Al}$ due to an increased $\mathrm{pH}$ obviously resulted in enhanced $\mathrm{P}$ retention, the $\mathrm{P}$ uptake was higher in the soils treated with peat ash and basic slag than in those amended with conventional liming agents.
\end{abstract}

\section{Introduction}

Finnish soils are typically acid and rather poor in available $\mathrm{P}$. Therefore liming and $\mathrm{P}$ fertilization are essential measures in agriculture. As shown e.g. by SALONEN et al. (1973), the utilization of added $\mathrm{P}$ by plants is, however, markedly dependent on the $\mathrm{P}$ sorption properties of soil. Phosphate retention, in turn, is affected by $\mathrm{pH}$ (OBIHARA and Russell 1972, Parfitt 1977, Barrow 1984 etc.). Therefore, liming can be expected to affect the phosphate-supplying power of soils.

In Finland, calcitic and dolomitic limestone is conventionally used as liming agent, but 
recently various basic waste materials and industrial byproducts have increasingly become available for this purpose. Yet, the information on the efficiency of these alternative liming materials, especially in relation to $\mathrm{P}$ nutrition of plants, is still insufficient. The purpose of the present pot experiment was to compare the $\mathrm{P}$ utilization by turnip rape in two acid mineral soils amended with peat ash or basic slag with that in soils treated with calcitic or dolomitic limestone. The impact of various liming materials on soil properties and $\mathrm{P}$ extractability was investigated in more detail in a concurrent incubation experiment.

\section{Materials and methods}

Two acid surface soil samples were taken from the experimental farm of Helsinki University. Their characteristics are given in Table 1. For the pot experiment, carried out in 1980 and 1981, Mitscherlich-pots were filled with $4.5 \mathrm{~kg}$ of moist soil, corresponding to $3.9 \mathrm{~kg}$ of air-dried muddy fine sand and $3.6 \mathrm{~kg}$ of air-dried fine sand. The soils were treated with $24 \mathrm{~g}$ of calcitic limestone, dolomitic limestone, peat ash or basic slag.

The liming agents contained various $P$ fractions, analyzed by a slightly modified CHANG and JACKSON method according to Hartikainen (1979) as follows:

\begin{tabular}{lcccc}
\hline & \multicolumn{4}{c}{$\mathrm{P}(\mathrm{mg} / \mathrm{kg})$ extracted by } \\
\cline { 2 - 5 } & $\mathrm{NH}_{4} \mathrm{Cl}$ & $\mathrm{NH}_{4} \mathrm{~F}$ & $\mathrm{NaOH}$ & $\mathrm{H}_{2} \mathrm{SO}_{4}$ \\
\hline Calcite & 0.4 & 0.0 & 1.5 & 0.0 \\
Dolomite & 0.1 & 0.0 & 1.5 & 0.0 \\
Peat ash & 569 & 906 & 322 & 4828 \\
Basic slag & 2.1 & 17.5 & 0.0 & 20.8 \\
\hline
\end{tabular}

The other properties have been reported by JOKINEN (1982).

Half of the pots were amended with $400 \mathrm{mg}$ of $\mathrm{P}$ (added as $\mathrm{K}_{2} \mathrm{HPO}_{4}$ ), corresponding to $104 \mathrm{mg}$ and $114 \mathrm{mg}$ per $\mathrm{kg}$ of the muddy fine sand and fine sand, respectively. The pots not treated with $\mathrm{P}$ received an equivalent quantity of $\mathrm{K}$ as $\mathrm{KCl}$. The amounts of other
Table 1. Characteristics of experimental soil samples.

\begin{tabular}{|c|c|c|}
\hline & $\begin{array}{l}\text { Muddy } \\
\text { fine sand }\end{array}$ & Fine sand \\
\hline Clay $\%$ & 22.4 & 22.5 \\
\hline $\mathrm{pH}\left(\mathrm{CaCl}_{2}\right)$ & 4.8 & 4.8 \\
\hline Org. C $\%$ of D. M. & 3.0 & 6.4 \\
\hline \multicolumn{3}{|l|}{ P-fractions } \\
\hline $\mathrm{NH}_{4} \mathrm{Cl}-\mathrm{P}$ ppm & 3.4 & 10.0 \\
\hline $\mathrm{NH}_{4} \mathrm{~F}-\mathrm{P} \quad "$ & 107 & 321 \\
\hline $\mathrm{NaOH}-\mathrm{P} \quad "$ & 286 & 277 \\
\hline $\mathrm{H}_{2} \mathrm{SO}_{4}-\mathrm{P} \quad m$ & 325 & 285 \\
\hline $\mathrm{KCl}$-extractable $\mathrm{Al}$ ppm & 44.8 & 29.7 \\
\hline $\mathrm{NH}_{4} \mathrm{OAc}-" n " n$ & 130.0 & 176.4 \\
\hline
\end{tabular}

plant nutrients applied to all soils are given in a previous paper (HARTIKAINEN 1983 b). Twenty seeds of turnip rape (Brassica campestris v. oleifera f. annua) were sown in each pot.

In an analogous incubation experiment, performed in plastic pots, the quantities of soils, liming agents and plant nutrient salts were $1 / 10$ of those used in the pot experiment. Both experiments were carried out with four replicates.

Plant analyses. After harvesting, the plant material was first dried at $60^{\circ} \mathrm{C}$ and thereafter heated at $105^{\circ} \mathrm{C}$ for two hours, grounded and digested with the acid mixture of $\mathrm{HClO}_{4}: \mathrm{H}_{2} \mathrm{SO}_{4}: \mathrm{HNO}_{3}(1: 2,5: 10)$ (SCHARRER and MUNK 1956). The filtered extracts were analyzed for $\mathrm{P}$ by an ammonium vanadate method (JACKSON 1958).

Soil analyses. In the incubation experiment, air-dried subsamples were analyzed after 4 and 16 months of incubation, in the pot experiment after 2 years of cultivation. Soil $\mathrm{pH}$ was measured in $0.01 \mathrm{M} \mathrm{CaCl}_{2}$ solution. Water-soluble $\mathrm{P}$ was extracted by a slightly modified van der PAAUw (1971) and SissingH (1971) method. Inorganic P was fractionated according to a modified CHANG and JACKSON method (HartiKainen 1979). The exchangeable $\mathrm{Al}$ was displaced with four portions of $1 \mathrm{M} \mathrm{KCl}$ in the ratio of soil to solution of $1: 5$ $(w / v)$ and determined by an Aluminon method of YUAN and Fiskell (1959). 


\section{Results}

a) Incubation experiment

The base strength of the liming agents, rated by comparing their effects on the soil $\mathrm{pH}$, varied markedly and decreased in both

Table 2. $\mathrm{pH}$ and exchangeable $\mathrm{Al}$ in soil samples incubated for 4 months with or without various liming agents.*

\begin{tabular}{|c|c|c|c|c|}
\hline \multirow{2}{*}{$\begin{array}{l}\text { Liming } \\
\text { treatment }\end{array}$} & \multicolumn{2}{|c|}{$\mathrm{pH}\left(\mathrm{CaCl}_{2}\right)$} & \multicolumn{2}{|c|}{$\mathrm{Al} \mathrm{mg} / \mathrm{kg}$} \\
\hline & - & $\mathrm{P}$ added & - & $\mathrm{P}$ added \\
\hline \multicolumn{5}{|c|}{ Muddy fine sand } \\
\hline Unlimed & $4.3^{\mathrm{a}}$ & $4.4^{a}$ & $99.2^{z}$ & $88.8^{f}$ \\
\hline Calcite & $6.4^{8}$ & $6.5^{\mathrm{h}}$ & $7.3^{\mathrm{a}}$ & $6.7^{\mathrm{a}}$ \\
\hline Dolomite & $6.0^{f}$ & $5.9^{f}$ & $6.9^{\mathrm{a}}$ & $6.9^{\mathrm{a}}$ \\
\hline Peat ash & $4.6^{b}$ & $4.7^{\mathrm{c}}$ & $61.3^{e}$ & $50.1^{d}$ \\
\hline Basic slag & $5.1^{\mathrm{d}}$ & $5.2^{e}$ & $18.2^{c}$ & $14.1^{\mathrm{b}}$ \\
\hline \multicolumn{5}{|c|}{ Fine sand } \\
\hline Unlimed & $4.5^{\mathrm{a}}$ & $4.5^{\mathrm{a}}$ & $63.9^{f}$ & $54.4^{e}$ \\
\hline Calcite & $5.9^{\circ}$ & $5.9^{e}$ & $6.9^{\mathrm{a}}$ & $7.5^{\mathrm{a}}$ \\
\hline Dolomite & $5.6^{\mathrm{d}}$ & $5.6^{d}$ & $5.9^{\mathrm{a}}$ & $6.7^{\mathrm{a}}$ \\
\hline Peat ash & $4.7^{\mathrm{b}}$ & $4.7^{b}$ & $40.4^{d}$ & $34.1^{\mathrm{c}}$ \\
\hline Basic slag & $5.1^{\mathrm{e}}$ & $5.1^{\mathrm{e}}$ & $14.3^{b}$ & $12.6^{b}$ \\
\hline
\end{tabular}

* Both soils are tested separately. The means followed by a common letter do not differ at $\mathrm{P}=0.05$.

Table 3. Water-soluble $\mathbf{P}$ in the soils incubated with various liming agents without $\mathrm{P}$ addition and the recovery of added $\mathrm{P}$ in water-soluble fraction.*

\begin{tabular}{|c|c|c|c|c|}
\hline \multirow{3}{*}{$\begin{array}{l}\text { Liming } \\
\text { agent }\end{array}$} & \multicolumn{2}{|c|}{$\mathrm{H}_{2} \mathrm{O}$-soluble $\mathrm{P} \mathrm{mg} / \mathrm{kg}$} & \multicolumn{2}{|c|}{ Recovery $\%$} \\
\hline & \multicolumn{4}{|c|}{ Incubation time, months } \\
\hline & 4 & 16 & 4 & 16 \\
\hline \multicolumn{5}{|c|}{ Muddy fine sand } \\
\hline Unlimed & $5.4^{\mathrm{a}}$ & $5.7^{\mathrm{abc}}$ & 8.0 & 5.5 \\
\hline Calcite & $7.3^{\mathrm{e}}$ & $6.1^{\text {abced }}$ & 8.2 & 6.3 \\
\hline Dolomite & $6.8^{\mathrm{de}}$ & $6.6^{\text {ede }}$ & 7.7 & 6.4 \\
\hline Peat ash & $5.8^{\mathrm{abc}}$ & $6.5^{\text {bede }}$ & 7.4 & 5.3 \\
\hline Basic slag & $5.5^{\mathrm{a}}$ & $5.6^{\mathrm{ab}}$ & 8.3 & 6.6 \\
\hline \multicolumn{5}{|c|}{ Fine sand } \\
\hline Unlimed & $28.9^{\mathrm{e}}$ & $29.5^{\mathrm{e}}$ & 15.0 & 12.2 \\
\hline Calcite & $23.6^{\mathrm{b}}$ & $20.7^{a}$ & 11.9 & 8.7 \\
\hline Dolomite & $24.9^{\text {bed }}$ & $23.8^{\mathrm{bc}}$ & 10.8 & 8.1 \\
\hline Peat ash & $29.1^{\mathrm{e}}$ & $26.5^{\mathrm{d}}$ & 10.1 & 10.6 \\
\hline Basic slag & $25.6^{\mathrm{cd}}$ & $24.9^{\text {bod }}$ & 12.7 & 10.3 \\
\hline
\end{tabular}

* Both soils are tested separately. experimental soils in the following sequence: calcite $>$ dolomite $>$ basic slag $>$ peat ash (Table 2). The peat ash treatment did not totally counterbalance a decrease in soil $\mathrm{pH}$ due to incubation and nutrient salt addition (from 4.8 to $4.3-4.5$ ). A prolonged incubation did not significantly affect the soil acidity. That is why the $\mathrm{pH}$ values at the end of the experiment only are presented.

All the liming materials were more effective in the muddy fine sand soil. Its lower $\mathrm{pH}$ buffering power appeared also in that the $\mathrm{pH}$ in soils amended with $\mathrm{K}_{2} \mathrm{HPO}_{4}$ tended to be a little higher than in those without $\mathrm{P}$ addition. Table 2 further reveals that the efficiency of various liming agents to reduce the exchangeable $\mathrm{Al}$ was related to their ability to decrease soil acidity. As expected, in the calcite- and dolomite-treated soils with final $\mathrm{pH}$ of $5.9-6.5$, this $\mathrm{Al}$ fraction had practically disappeared. In the other treatments, the $\mathrm{P}$ addition resulted in a further depression in exchangeability of $\mathrm{Al}$.

In the experimental soils a reduction in acidity affected the solubility of $P$ in an opposite direction. Table 3 shows that the 4-month incubation tended to increase the water-soluble $\mathrm{P}$ in the muddy fine sand and to decrease that in the fine sand soil. The data reveal also a tendency of $\mathrm{P}$ intensity being the more affected the more a given liming agent raised the $\mathrm{pH}$. A long-term incubation reduced the solubility of $\mathrm{P}$ into water in the calcite-treated samples and in the fine sand samples supplied with peat ash. Further, the sorption of added $\mathrm{P}$ was lower by the fine sand richer in native water-soluble $\mathrm{P}$ than by the muddy fine sand soil (Table 3 ). After a 4-month incubation, water extracted $7.4-8.3 \%$ of the $\mathrm{P}$ added to the muddy fine sand soil and $10.1-15.0 \%$ of $P$ added to the fine sand soil. The recovery data indicate the impact of liming to have been quite similar on fertilizer $\mathrm{P}$ and the soil $\mathrm{P}$ resources. The prolonged treatment reduced the recovery in all soils.

According to the results of the fractionation analyses (data not presented) the various 
liming treatments tended to decrease the $\mathrm{NaOH}$-soluble P (by $9-23 \mathrm{mg} / \mathrm{kg}$ ) and to increase the $\mathrm{NH}_{4} \mathrm{~F}$-soluble $\mathrm{P}$ (by $4-28 \mathrm{mg}$ / $\mathrm{kg}$ ), to some extent also the $\mathrm{H}_{2} \mathrm{SO}_{4}$-extractable fraction (by $0-12 \mathrm{mg} / \mathrm{kg}$ ), in the soils incubated without $\mathrm{P}$ addition. It its noteworthy, however, that in the soils supplied with peat ash also the $\mathrm{NaOH}-\mathrm{P}$ was markedly increased (by $26-30 \mathrm{mg} / \mathrm{kg}$ ). In fact, the $\mathrm{P}$ applied with peat ash was recovered mainly in the $\mathrm{NH}_{4} \mathrm{~F}$ - and $\mathrm{NaOH}$-soluble fractions.

\section{b) Pot experiment}

Table 4 shows that the liming agents affected the dry matter yields only in the second year. In the muddy fine sand the shoot yields increased, except in the dolomite-treated soils. In the fine sand soil, on the other hand, only dolomite and basic slag significantly improved plant growth. In this soil, also the positive effect of $\mathrm{P}$ addition appeared just in the second harvest, in the unlimed or calcitetreated soils. Inversely, the $\mathrm{P}$ fertilization was necessary for the muddy fine sand. In the first year it did not affect plant growth in soil supplied with basic slag, but its positive residual effect was marked also in this treatment.

In general, the $\mathrm{P}$ content was higher in the shoots harvested from the fine sand soil than in those harvested from the muddy fine sand: without $\mathrm{P}$ fertilization the range in the first yield was 3.50-4.68\% and 3.82$4.30 \%$, in the second one $2.24-3.46 \%$ and $2.46-2.69 \%$, respectively. Table 5 reveals that the $\mathrm{P}$ removal from the muddy fine sand soil without $P$ addition was not affected by the liming agents in the first year, but was markedly promoted by the peat ash and calcite treatments in the second year. The residual effect of ash was noticeable even in soils fertilized with P. In terms of total uptake the dolomite seemed to be the least effective.

In the fine sand soil, on the contrary, the liming treatments did not significantly enhance the $\mathrm{P}$ withdrawal despite increased dry matter yields. There was rather a tendency of the calcite and dolomite additions impeding the $\mathrm{P}$ nutrition also in the soils supplied with fertilizer P. Only the P treatment was capable of promoting the $\mathrm{P}$ uptake, but to a lesser extent than in the muddy fine sand. Further, a comparison between the various liming materials demonstrates the superiority of the peat ash and basic slag.

Although the withdrawal of soil $\mathrm{P}$ was intensified in the muddy fine sand soil by various liming materials, the residual water-

Table 4. Dry matter yields ( $\mathrm{g} / \mathrm{kg}$ of soil).*

\begin{tabular}{|c|c|c|c|c|c|c|}
\hline \multirow{2}{*}{$\begin{array}{l}\text { Liming } \\
\text { treatment }\end{array}$} & \multicolumn{2}{|c|}{ Year 1980} & \multicolumn{2}{|c|}{ Year 1981} & \multicolumn{2}{|c|}{ Total } \\
\hline & - & $\mathrm{P}$ applied & - & $\mathrm{P}$ applied & - & $\mathrm{P}$ applied \\
\hline \multicolumn{7}{|c|}{ Muddy fine sand } \\
\hline Unlimed & $5.3^{\mathrm{a}}$ & $9.2^{\text {cde }}$ & $1.3^{\mathrm{a}}$ & $4.4^{d}$ & $6.6^{\mathrm{a}}$ & $13.6^{c}$ \\
\hline Calcite & $6.5^{\mathrm{abc}}$ & $10.9^{e}$ & $3.8^{\mathrm{cd}}$ & $6.4^{e}$ & $10.3^{b}$ & $17.3^{\mathrm{gd}}$ \\
\hline Dolomite & $5.6^{\mathrm{ab}}$ & $9.6^{\mathrm{de}}$ & $2.3^{\mathrm{ab}}$ & $4.5^{\mathrm{d}}$ & $7.9^{\mathrm{ab}}$ & $14.1^{\mathrm{c}}$ \\
\hline Peat ash & $5.6^{\mathrm{ab}}$ & $9.5^{\mathrm{de}}$ & $3.9 \mathrm{~cd}$ & $6.6^{e}$ & $9.5^{\mathrm{ab}}$ & $16.1^{\text {cd }}$ \\
\hline Basic slag & $7.1^{\text {abcd }}$ & $8.3^{\text {bede }}$ & $2.9^{b c}$ & $6.5^{e}$ & $10.0^{b}$ & $14.8^{\mathrm{cd}}$ \\
\hline \multicolumn{7}{|c|}{ Fine sand } \\
\hline Unlimed & $8.4^{a b}$ & $10.1^{\mathrm{ab}}$ & $5.7^{a}$ & $7.8^{\mathrm{bc}}$ & $14.1^{\mathrm{a}}$ & $17.9^{\text {bed }}$ \\
\hline Calcite & $8.1^{\mathrm{a}}$ & $10.6^{\mathrm{ab}}$ & $6.4^{\mathrm{ab}}$ & $8.9^{\circ}$ & $14.5^{\mathrm{ab}}$ & $19.5^{d}$ \\
\hline Dolomite & $8.8^{\mathrm{ab}}$ & $11.3^{b}$ & $7.4^{\mathrm{bc}}$ & $7.5^{\mathrm{bc}}$ & $16.2^{\text {abcd }}$ & $18.8^{\text {cd }}$ \\
\hline Peat ash & $8.2^{\mathrm{a}}$ & $8.8^{\mathrm{ab}}$ & $7.1^{\mathrm{ab}}$ & $8.1^{\text {bc }}$ & $15.3^{\mathrm{abc}}$ & 16.9abcd \\
\hline Basic slag & $7.9^{a}$ & $9.4^{\mathrm{ab}}$ & $7.6^{\mathrm{bc}}$ & $8.9^{\circ}$ & $15.5^{\mathrm{abc}}$ & $18.3^{\text {bcd }}$ \\
\hline
\end{tabular}

* Both soils and years are tested separately. 
soluble P was slightly decreased only in the basic slag treatment (Table 6). In the fine sand soil, on the contrary, the residual watersoluble $\mathrm{P}$ decreased by liming, but not by peat ash treatment. In most cases the liming treatments did not affect the extractability of residual $\mathrm{P}$ in the soils supplied with $\mathrm{K}_{2} \mathrm{HPO}_{4}$. Only the calcite-induced reduction in the fine sand soil was statistically significant.

\section{Discussion}

In the muddy fine sand soil poor in watersoluble $\mathrm{P}$, the first dry matter yields increased by the $\mathrm{P}$ additions but were not affected by the liming agents. This suggests the shortage of $\mathrm{P}$ to have been a growth-limiting factor. The fine sand soil contained abundantly easily soluble $\mathrm{P}$. Therefore the $\mathrm{P}$ fertilization showed some positive effect only in the second year after the resources were depleted by the withdrawal of the first harvest.

The various liming treatments affected the shoot yields and the P uptake only in the second year. In the P-deficient muddy fine sand, a liming-induced increase in $\mathrm{P}$ removal seemed to be associated with an increase in dry matter yields, whereas in the fine sand soil there was no unambiguous relationship between the quantities of plant material harvested and $P$ withdrawal. In fact, the incubation test showed that the experimental soils

Table 5. Amounts of $\mathrm{P}(\mathrm{mg} / \mathrm{kg}$ of soil) taken up by yields.*

\begin{tabular}{|c|c|c|c|c|c|c|}
\hline \multirow{2}{*}{$\begin{array}{l}\text { Liming } \\
\text { treatment }\end{array}$} & \multicolumn{2}{|c|}{ Year 1980} & \multicolumn{2}{|c|}{ Year 1981} & \multicolumn{2}{|c|}{ Total } \\
\hline & - & $\mathrm{P}$ applied & - & $\mathrm{P}$ applied & - & $\mathbf{P}$ applied \\
\hline \multicolumn{7}{|c|}{ Muddy fine sand } \\
\hline Unlimed & $19.4^{\mathrm{a}}$ & $41.7^{\mathrm{c}}$ & $3.4^{\mathrm{a}}$ & $16.1^{d}$ & $22.8^{\mathrm{a}}$ & $57.8^{\mathrm{cd}}$ \\
\hline Calcite & $24.3^{a}$ & $48.1^{\mathrm{c}}$ & $9.5^{\mathrm{bc}}$ & $16.0^{d}$ & $33.8^{\mathrm{b}}$ & $64.1^{\text {cd }}$ \\
\hline Dolomite & $24.1^{\text {a }}$ & $42.3^{c}$ & $5.4^{\mathrm{ab}}$ & $12.6^{\mathrm{cd}}$ & $29.5^{\mathrm{ab}}$ & $54.9^{c}$ \\
\hline Peat ash & $23.2^{\mathrm{a}}$ & $43.6^{c}$ & $10.3^{\mathrm{c}}$ & $21.6^{e}$ & $33.5^{b}$ & $65.2^{\mathrm{d}}$ \\
\hline Basic slag & $29.1^{\mathrm{ab}}$ & $37.1^{\mathrm{bc}}$ & $7.2^{\mathrm{ab}}$ & $16.9^{\mathrm{de}}$ & $36.3^{b}$ & $54.0^{c}$ \\
\hline \multicolumn{7}{|c|}{ Fine sand } \\
\hline Unlimed & $38.5^{\mathrm{ab}}$ & $50.0^{\mathrm{bc}}$ & $20.1^{\mathrm{ab}}$ & $33.1^{f}$ & $58.6^{\mathrm{ab}}$ & $83.1^{c}$ \\
\hline Calcite & $33.0^{\mathrm{a}}$ & $45.5^{\mathrm{abc}}$ & $16.7^{\mathrm{a}}$ & $27.4^{\text {ede }}$ & $49.7^{\mathrm{a}}$ & $72.9^{\mathrm{bc}}$ \\
\hline Dolomite & $33.2^{\mathrm{a}}$ & $56.4^{c}$ & $16.6^{a}$ & $23.4^{\mathrm{bcd}}$ & $49.8^{\mathrm{a}}$ & $79.8^{c}$ \\
\hline Peat ash & $33.6^{a}$ & $45.7^{a b c}$ & $23.1^{\mathrm{bc}}$ & $32.3^{\text {ef }}$ & $56.7^{a}$ & $78.0^{c}$ \\
\hline Basic slag & $35.3^{\mathrm{ab}}$ & $47.7^{a b c}$ & $24.1^{\text {bed }}$ & $28.5^{\text {def }}$ & $59.4^{\mathrm{ab}}$ & $76.2^{c}$ \\
\hline
\end{tabular}

* Both soils and years are tested separately.

Table 6. Effects of various liming treatments on residual water-soluble $\mathrm{P}(\mathrm{mg} / \mathrm{kg})$ in cultivated soils.

\begin{tabular}{|c|c|c|c|c|}
\hline \multirow[b]{2}{*}{ Liming agent } & \multicolumn{2}{|c|}{ Muddy fine sand } & \multicolumn{2}{|c|}{ Fine sand } \\
\hline & - & $\mathrm{P}$ applied & - & $\mathrm{P}$ applied \\
\hline Calcite & $-0.08^{\mathrm{ns}}$ & $+0.07^{\mathrm{ns}}$ & $-6.84^{* * *}$ & $-4.80^{*}$ \\
\hline Dolomite & $-0.36^{\mathrm{ns}}$ & $+0.99^{\mathrm{ns}}$ & $-5.25 * *$ & $-4.20^{\mathrm{ns}}$ \\
\hline Peat ash & $-0.16^{\mathrm{ns}}$ & $+0.73^{\mathrm{ns}}$ & $+0.33^{n s}$ & $+2.40^{\mathrm{ns}}$ \\
\hline Basic slag & $-0.98^{*}$ & $-1.04^{\mathrm{ns}}$ & $-2.46^{*}$ & $+1.35^{\mathrm{ns}}$ \\
\hline
\end{tabular}

ns. $=$ not significant

$* \quad=\mathrm{P}<0.05$

$* *=\mathrm{P}<0.01$

$* * *=\mathrm{P}<0.001$ 
represented soil types of dissimilar responses to liming treatment in regard to $\mathrm{P}$ extractability: in the muddy fine sand soil the watersoluble $\mathrm{P}$ tended to increase and in the fine sand soil to decrease with rising $\mathrm{pH}$, irrespective of the liming material used. This observation was made also in a previous incubation study where the same soil samples were treated with increasing quantities of calcite (HARTIKAINEN 1983 a).

The results of the pot experiment reveal, however, that the efficiency of different liming agents in improving plant growth or $\mathrm{P}$ withdrawal was not related to their capacity to reduce the soil acidity. In both soils, $\mathrm{pH}$ was raised most by calcite, followed by dolomite, basic slag and peat ash. Nevertheless, in the muddy fine sand soil cultivated without $\mathrm{P}$ addition calcite and peat ash increased most effectively the shoot yields and the basic slag was superior to dolomite. Except for dolomite, the liming agents significantly enhanced also the total P uptake. However, despite increased $\mathbf{P}$ removal, the residual water-soluble $\mathrm{P}$ was slightly decreased only in the basic slag treatment, which allows to conclude that these agents increased the available $\mathrm{P}$ in soil.

In the fine sand soil, the efficiency sequence of the liming materials was dissimilar: dolomite and basic slag significantly increased the dry matter yields in soils not treated with $\mathrm{P}$, but the effect of calcite and peat ash remained insignificant. However, only basic slag and peat ash tended to promote the $\mathrm{P}$ uptake, whereas the conventional liming agents seemed to depress it, even in soils fertilized with $\mathrm{K}_{2} \mathrm{HPO}_{4}$. Also the residual water-soluble $\mathrm{P}$ in the calcite- and dolomite-treated soils was decreased, which gives a further indication of a reduction in $\mathrm{P}$ availability.

These results suggest that, in addition to the neutralizing ability, also other properties of the liming agents were conducive. Peat ash rich in $\mathrm{P}$ obviously served as a slowly acting $\mathrm{P}$ fertilizer rather than as a liming agent. It is noteworthy that the $\mathrm{P}$ contained in the ash was mainly of an acid-soluble form, but after a 4-month incubation in soil the bulk of it was recovered in $\mathrm{NH}_{4} \mathrm{~F}$ - and $\mathrm{NaOH}$-extractable fractions. This indicates the solubility of $\mathrm{P}$ to have increased during the incubation. Thus, it seems likely that it took longer than one year for the peat ash to benefit the P-deficient muddy fine sand.

Inversely, the basic slag was very poor in $\mathrm{P}$, but contained abundantly $\mathrm{Si}$ which was shown in several studies (reviewed e.g. by FidANOvSKI (1968)) to intensify plant growth. There are numerous interpretations of the mechanism of action of Si. In the present study, however, its beneficial effect seemed to be attributable to an increased availability of soil $\mathrm{P}$ due to the silicate addition, as reported by Semb (1943), Ganssmann (1961), etc. Silicate is specifically sorbed by soil colloids (Hingston et al. 1967) and its addition is known to result in the desorption of previously sorbed phosphate (OBIHARA and Russell 1972, Smyth and Sanchez 1980).

In contrast to some earlier studies (e.g. SCHEFFER et al. 1982), the phosphate mobilization by silicate seemed to occur despite a relatively low soil $\mathrm{pH}$. Recently, also HAYNES (1984) has stated the $\mathrm{pH}(\mathrm{KCl})$ values to be lower in soils amended with $\mathrm{CaSiO}_{3}$ than in soils treated with a chemically equivalent quantity of $\mathrm{Ca}(\mathrm{OH})_{2}$, but the effect of form of liming material on estimates of phosphate availability depended upon the soil extractant used. Accordingly, the extraction test of SCHEFFER and SCHEFFER (1984) demonstrated the silicate addition to increase calcium lactate-soluble $\mathrm{P}$ less than did lime, but the pot experiment showed the silicic acid effect of Hüttenkalk to be of longer duration than that of $\mathrm{CaO}$.

It should be pointed out, however, that in the present study no liming-induced increase in the $\mathrm{P}$ uptake amounted to that brought about by a rather high $\mathrm{P}$ addition. Nevertheless, in the unlimed muddy fine sand, an increase in shoot yield due to the $\mathrm{P}$ fertilization did not significantly differ from that caused in the first year by calcite and 
basic slag treatment, and in the second year by calcite and peat ash treatment. Further, the comparison of present results with those obtained by JOKINEN (1982) with the same soils without $\mathrm{Mg}$ addition supports the conclusion that the growth-promoting effect of basic slag and peat ash would be attributable to their impact on $\mathrm{P}$ resources rather than to their role as $\mathrm{Mg}$ or Ca sources.

The efficiency sequence of the liming materials was dissimilar in the experimental soils, indicating the usefulness of a given agent to be controlled also by soil properties. In the fine sand soil, the inefficiency of peat ash and basic slag to elevate soil $\mathrm{pH}$ was a factor actually promoting the availability of P. A previous study (HaRTIKAINEN 1983 a) implied the detrimental effect of liming in this soil to be attributable to the abundance of polymerized $\mathrm{Al}$ the affinity of which for $\mathrm{P}$ retention increased with increasing $\mathrm{pH}$. It can be supposed that much higher quantities of limestone are needed to overrule the polymerization of $\mathrm{Al}$ and to start the desorption of $\mathrm{P}$. The results demonstrate that base quantities adequate to neutralize the exchangeable $\mathrm{Al}$ cannot be used as a reliable measure of lime requirement, especially in soils rich in organic matter.

The P mobility estimates obtained in the incubation experiment by simple water extraction seemed to underestimate the efficiency of the alternative liming agents in promoting the $\mathrm{P}$ uptake. Obviously, this was partly due to a high nutrient salt application enhancing the $\mathrm{P}$ adsorption. Further, the $\mathrm{pH}$ data of limed soils suggest that, as far as the $\mathrm{P}$ nutrition of plants is concerned, the usefulness of various materials cannot be evaluated only on the basis of their neutralizing ability.

\section{References}

Barrow, N.J. 1984. Modelling the effects of $\mathrm{pH}$ on phosphate sorption by soils. J. Soil Sci. 35: 283-297.

Fidanovskı, F. 1968. Silicium, ein für die Pflanzen nützliches Element. Z. Pflanzenernähr. Bodenkd. 120: $191-207$.

Ganssmann, W. 1961. Über die Siliziumbestimmung in Pflanzen und die Aufnahme von Phosphorsäure und anderen Nährstoffen bei Siliziumdüngung. 130 p. Giessen.

Hartikainen, H. 1979. Phosphorus and its reactions in terrestrial soils and lake sediments. J. Scient. Agr. Soc. Finl. 51: 537-623.

Hartikainen, H. 1983 a. Effect of liming on phosphorus in two soils of different organic matter content. I Changes of native and applied phosphorus in incubation experiment. J. Scient. Agr. Soc. Finl. 55: 345-354.

Hartikainen, H. 1983 b. Effect of liming on phosphorus in two soils of different organic matter content. II Changes in the availability of phosphorus to turnip rape (Brassica campestris). J. Scient. Agr. Soc. Finl. 55: $355-362$.

Haynes, R.J. 1984. Effect of lime, silicate, and phosphate applications on the concentrations of extractable aluminium and phosphate in a Spodosol. Soil Sci. 138: $8-14$.

Hingston, F.J., Atkinson, R.J., Posner, A.M. \& Quirk, J.P. 1967. Specific adsorption of anions. Nature 215: 1459-1461.

JACKSON, M.L. 1958. Soil chemical analyses. 498 p. London.

JOKINEN, R. 1982. The efficiency of dolomitic limestone, basic slag and peat ash as liming agents, and as calcium and magnesium sources for turnip rape. J. Scient. Agr. Soc. Finl. 54: 371-383.

Jones, L.D.H. \& HANDRECK, K.H. 1967. Silica in soils, plants and animals. Advances in Agronomy 19: 107 -149 .

Obihara, C.H. \& Russell, E.W. 1972. Specific adsorption of silicate and phosphate by soils. J. Soil Sci. 23; 105-117.

PaAuw, F. van der. 1971. An effective water extraction method for the determination of plant-available soil phosphorus. Plant and Soil 34: 467-481.

PARFITT, R.L. 1977. Phosphate adsorption on an Oxisol. Soil Sci. Soc. Amer. J. 41: 1064-1067.

Salonen, M., Koskela, I. \& Kähäri, J. 1973. The dependence of the phosphorus uptake of plants on the properties of the soil. Ann. Agr. Fenn. 12: 161-171.

Scharrer, K. \& Munk, H. 1956. Zur Methodik der nassen Veraschung in der agrikulturchemischen Analyse. Agrochimica 1: 44-55. 
Scheffer, B. \& Scheffer, K. 1984. Der Einfluss von Kalk und Kieselsăure auf die Phosphatmobilităt (CAL) in Böden. Landwirtsch. Forschung 37: 1-8.

Scheffer, K., Schreiber, A. \& Kickuth, R. 1982. Die sorptive Bindung von Düngerphosphaten im Boden und die phosphatmobilisierende Wirkung der-Kieselsäure. 2. Mitteilung: Die mobilisierende Wirkung der Kieselsăure. Arch. Acker- u. Pflanzenbau u. Bodenkd. 26: 143-152.

Semb, G. 1943. Undersøkelser over fosforsyrens oppløselighet og binding i østnorske jordtyper. Meldinger fra Norges Landbrukshøgskole. 1-145.

Sissingh, H.A. 1971. Analytical technique of Pw meth- od, used for the assessment of the phosphate status of arable soils in the Netherlands. Plant and Soil 34: $483-486$.

Smyth, T.J. \& Sanchez, P.A. 1980. Effects of lime, silicate, and phosphorus applications to an Oxisol on phosphorus sorption and ion retention. Soil Sci. Soc. Amer. J. 44: 500-505.

Yuan, T.L. \& Fiskell, J.G.A. 1959. Aluminium determination. Aluminium studies. Soil and plant analysis of aluminium by modification of the Aluminium method. J. Agr. Food Chem. 7: 115-117.

Ms received December 5, 1984

\section{SELOSTUS}

\section{Turpeen tuhka ja masuunikuona kalkitusaineina kevätrypsin fosforin saannin kannalta}

\author{
Helinä Hartikainen \\ Helsingin yliopisto, Maanviljelyskemian laitos, \\ 00710 HELSINKI
}

Kaksi kasvukautta kestäneessä astiakokeessa vertailtiin kevătrypsin fosforin ottoa kalkitsemattomista sekä turvevoimalan arinatuhkalla, masuunikuonalla, kalsiittikalkilla tai dolomiittikalkilla käsitellyistä maista. Kalkitusaineita lisăttiin yhtä suuret măărăt. Kaikki koejäsenet saivat muuten samanlaisen peruslannoituksen, mutta puolet astioista jätettiin ilman fosforilisäystä. Kalkituskäsittelyjen vaikutuksia maanäytteiden fosforitilaan sekä muihin kemiallisiin ominaisuuksiin selvitettiin koejärjestelyltäăn astiakoetta vastanneen muhituskokeen avulla. Kokeissa käytettiin kahta hapanta $\left(\mathrm{pH}_{\mathrm{CaCl}_{2}} 4.8\right)$ hietamaanäytettä.

Kalkitusaineiden happamuutta neutraloiva vaikutus pieneni järjestyksessä: kalsiitti > dolomitti > masuunikuona $>$ turpeen tuhka. Ne edistivăt toisena vuonna kevätrypsin kasvua, mutta sadonlisäykset eivăt seuranneet happamuuden văhenemistä. Fosforitilaltaan huonossa liejuisessa hienossa hiedassa (3.0\% org. C) turpeen tuhka ja masuunikuona nostivat kuiva-ainesatoja yhtả paljon kuin kalsiitti. Karkeassa hiedassa (6.4 \% org. C) sadot nousivat masuunikuonalla ja dolomiitilla käsitellyissä maissa.
Turpeen tuhkan ja masuunikuonan tehokkuus perustui ilmeisesti niiden suotuisaan vaikutukseen maan fosforivaroihin. Tuhka sisălsi runsaasti happoliukoista fosforia, jonka liukoisuus näytti paranevan muhituksen aikana. Sen katsottiinkin toimineen pikemminkin hidasvaikutteisena fosforilannoitteena kuin kalkitusaineena. Masuunikuonan vaikutus perustui ilmeisesti siihen, ettă silikaatti-ionien konsentraation kasvu edisti fosforin vapautumista pidătyspaikoilta. Văhăn helppoliukoista fosforia sisältäneessä liejuisessa hienossa hiedassa turpeen tuhka ja kalsiitti paransivat fosforin ottoa yhtä tehokkaasti. Sen sijaan karkeassa hiedassa kalsiitti ja dolomiitti heikensivăt fosforin saantia. Ilmeisesti $\mathrm{pH}: \mathrm{n}$ nousu edisti aluminiumin polymeroitumista ja siten fosforin pidăttymistă. Tuhkalla ja masuunikuonalla käsitellyissä koejäsenissä $\mathrm{pH}$ :n nousu jäi varsin pieneksi ja fosfori säilyi käyttőkelpoisempana. Näyttäă siltā, ettă karkeassa hiedassa olisi kalsiitin ja dolomiitin mäărien pitänyt olla suurempia, jotta syntyneiden Al-yhdisteiden pinnoille pidättynyttă fosforia olisi alkanut uudelleen mobilisoitua. 